\title{
The Cellular Code for Mammalian Thermosensation
}

\author{
Leah A. Pogorzala, Santosh K. Mishra, and Mark A. Hoon \\ Molecular Genetics Unit, Laboratory of Sensory Biology, National Institute of Dental and Craniofacial Research-National Institutes of Health, Bethesda, \\ Maryland 20892
}

\begin{abstract}
Mammalian somatosenory neurons respond to thermal stimuli and allow animals to reliably discriminate hot from cold and to select their preferred environments. Previously, we generated mice that are completely insensitive to temperatures from noxious cold to painful heat $\left(-5\right.$ to $\left.55^{\circ} \mathrm{C}\right)$ by ablating several different classes of nociceptor early in development. In the present study, we have adopted a selective ablation strategy in adult mice to study this phenotype and have demonstrated that separate populations of molecularly defined neurons respond to hot and cold. TRPV1-expressing neurons are responsible for all behavioral responses to temperatures between 40 and $50^{\circ} \mathrm{C}$, whereas TRPM8 neurons are required for cold aversion. We also show that more extreme cold and heat activate additional populations of nociceptors, including cells expressing Mrgprd. Therefore, although eliminating Mrgprd neurons alone does not affect behavioral responses to temperature, when combined with ablation of TRPV1 or TRPM8 cells, it significantly decreases responses to extreme heat and cold, respectively. Ablation of TRPM8 neurons distorts responses to preferred temperatures, suggesting that the pleasant thermal sensation of warmth may in fact just reflect reduced aversive input from TRPM8 and TRPV1 neurons. As predicted by this hypothesis, mice lacking both classes of thermosensor exhibited neither aversive nor attractive responses to temperatures between 10 and $50^{\circ} \mathrm{C}$. Our results provide a simple cellular basis for mammalian thermosensation whereby two molecularly defined classes of sensory neurons detect and encode both attractive and aversive cues.
\end{abstract}

\section{Introduction}

Thermosensation provides valuable information about the environment and triggers strong emotional and behavioral responses over a wide temperature range. For example, noxious heat and cold are highly unpleasant sensations that trigger powerful escape reactions in most animals. However, mammalian thermosensation does far more than simply trigger reflex withdrawal from painful heat or cold: for example, humans reliably distinguish unpleasantly hot and cold stimuli, whereas intermediate temperatures (e.g., cool or warm) can be very pleasant and drive attractive rather than aversive responses.

The ability of mammals to sense the temperature in their environment relies primarily on specialized somatosensory neurons in the trigeminal and dorsal root ganglia (DRG) that project axonal processes to the outer layers of the skin (Woolf and Ma, 2007). How are thermal cues encoded in these neurons at the periphery?

A major advance in the understanding of mammalian temperature sensation came with the characterization of TRPV1 as a high-temperature and capsaicin-gated channel that is expressed

\footnotetext{
Received Dec. 18, 2012; revised Jan. 25, 2013; accepted Feb. 5, 2013.

Author contributions: L.A.P., S.K.M., and M.A.H. designed research; L.A.P. and S.K.M. performed research; L.A.P., S.K.M., and M.A.H. analyzed data; M.A.H. wrote the paper.

This research was supported by the intramural research program of the National Institute of Dental and Craniofacial Research (NIDCR)-National Institutes of Health (M.A.H.). We thank Dr. David Anderson for providing MrgprdDTR mice, Nick Ryba for encouragement and helpful advice, and Drs. Minh Nguyen and Lars von Buchholtz and members of the Molecular Genetics Unit for valuable suggestions. Transgenic mice were generated by Andrew Cho in the NIDCR Core Facility.

Correspondence should be addressed to Mark A. Hoon, Molecular Genetics Unit, Laboratory of Sensory Biology, NIDCR, NIH Building 49, Room 1A16, 49 Convent Drive, Bethesda, MD 20892. E-mail: mark.hoon@nih.gov.

DOI:10.1523/JNEUROSCI.5788-12.2013

Copyright $\odot 2013$ the authors $\quad 0270-6474 / 13 / 335533-09 \$ 15.00 / 0$
}

in heat-sensitive DRG neurons (Caterina et al., 1997). Subsequent identification of TRPM8 as a low-temperature sensor (McKemy et al., 2002, Peier et al., 2002), as well as several other TRP channels that appear to be stimulated by either heating or cooling, led to the proposal that multiple TRP channels act in concert as differentially tuned "molecular thermometers" to orchestrate appropriate responses over a wide range of temperatures (Jordt et al., 2003, Patapoutian et al., 2003).

In keeping with its role as a putative cold-temperature sensor, knockout of TRPM8 results in a large selective deficit in an animal's ability to detect cool $\left(15-25^{\circ} \mathrm{C}\right)$ temperatures (Bautista et al., 2007, Colburn et al., 2007, Dhaka et al., 2007). However, knockout of other thermosensory TRP channels provides more modest support for this model (Kwan et al., 2006, Vriens et al., 2011), and the limited thermosensitive defect of TRPV1-KO mice has led to questions about the role of TRPV1 in vivo (Woodbury et al., 2004, Park et al., 2011). Nonetheless, agonist-dependent ablation (Karai et al., 2004, Mishra and Hoon, 2010) or silencing (Cavanaugh et al., 2009) of TRPV1 neurons results in significant deficits in sensing hot, suggesting that TRPV1 marks heatsensitive neurons. Unfortunately, resiniferatoxin-mediated ablation of TRPV1 cells is never complete (Mishra and Hoon, 2010) and the capsaicin-induced lesions (Cavanaugh et al., 2009) are largely undefined, reducing the strength of conclusions that can be drawn from this type of approach.

Recently, we generated mice that were completely insensitive to a very broad range of thermal stimuli (from -5 to $55^{\circ} \mathrm{C}$ ) (Mishra et al., 2011). In these animals, TRPV1-mediated expression of diphtheria toxin resulted in the ablation of several different molecular classes of nociceptor, including the TRPV1, TRPM8, and Mrgpr neurons, because TRPV1 is expressed in 
common precursor cells (Mishra et al., 2011). In the present study, we used a different molecular genetic approach to eliminate each of these neural classes selectively in adult mice and have thereby delineated a simple logic for the detection of temperatures spanning the entire physiologically relevant range.

\section{Materials and Methods}

Animal models

All procedures followed the NIH Guide for the Care and Use of Laboratory Animals and were approved by the National Institute of Dental and Craniofacial Research Animal Care and Use Committee. TRPV1-DTR and TRPM8DTR mice are BAC transgenic; BACs were engineered by recombineering (Lee et al., 2001) using RP23-181P10 and RP24-78N24, respectively, to generate transgenic constructs (Fig. 1a). As expected, before diphtheria toxin (DT) treatment, transgenically expressed GFP was readily detected in the appropriate number of somatosensory neurons. However, although we searched extensively outside of the peripheral ganglia in the brain and other organs that have been reported to express TRPV1 (Cavanaugh et al., 2011), we found no expression of GFP even when using sensitive antibody-staining techniques. Therefore, these BAC transgenes selectively target diphtheria toxin receptor (DTR) to the appropriate class of somatosensory neuron (Fig. 1 provides additional characterization). The other strains have been described previously: Mrgprd-DTR (a generous gift from David Anderson; Cavanaugh et al., 2009), TRPV1-DTA (Mishra et al., 2011), TRPM8 ${ }^{-1-}$ (Bautista et al., 2007), and TRPV ${ }^{-1-}$ (Caterina et al., 2000).

Animals were intercrossed to generate experimental animals (of either sex) as described in the text; the TRPV1DTR and TRPM8-DTR were hemizygous and Mrgprd-DTR heterozygous in all experiments. For DT-mediated cell ablation, we began administering DT in adult mice ( $>5$ weeks old); behavioral testing began at least 1 week and no more than 2 months after DT administration using mice weighing 20-30 g (2-4 months of age). Over this 2 month time period, repeat experiments established that phenotypes were completely stable. Control mice for each experimental series were DTtreated, nontransgenic littermates and were cohoused with DTR siblings. We tested mice in behavioral assays before recording their ear tag numbers, so experimenters were blind to the genotype of individual mice. No significant differences in behavior between different sets of controls were noted and, for simplicity, data were combined from the TRPV1-DTR and TRPM8-DTR littermate controls unless otherwise specified.

We established the effectiveness of DT-mediated ablation experimentally in the different lines and assessed the minimal dosage required to achieve $>95 \%$ elimination of target cells. For TRPM8-DTR animals, this required daily injection of DT (100 ng) for $7 \mathrm{~d}$; for TRPV1-DTR and Mrgprd-DTR animals, cell elimination was achieved by regular injection of $200 \mathrm{ng}$ of DT (administered for $5 \mathrm{~d}$, followed by $2 \mathrm{~d}$ off, for 3 weeks); double and triple mutants all received this higher DT dose. We used the TRPV1-DTR line to ensure that DT ablated cells from the ganglia by counting neurons in serial sections through the entire L4 ganglion of control (8660 \pm 667 NeuN-positive neurons) and DT-treated TRPV1DTR mice (5760 \pm 467 NeuN-positive neurons; significant difference between groups; $p<0.01$, Student's $t$ test, data are means \pm SEM; $n=4$ ). As expected, $\sim 33 \%$ of total neurons were lost, which is consistent with the selective loss of TRPV1-expressing neurons (Caterina et al., 2000).
Table 1. Body temperature of transgenic mice

\begin{tabular}{llllll}
\hline & & & & & \\
Control & TRPV1-DTR & TRPM8-DTR & Mrgprd-DTR & $\begin{array}{l}\text { TRPV1-DTR/ } \\
\text { TRPM8-DTR }\end{array}$ & $\begin{array}{l}\text { TRPM8-DTR/ } \\
\text { Trgprd-DTR }\end{array}$ \\
\hline $37.2 \pm 0.32$ & $37.3 \pm 0.31$ & $37.3 \pm 0.40$ & $37.3 \pm 0.21$ & $37.2 \pm 0.33$ & $37.1 \pm 0.20$
\end{tabular}

Body temperature $\left({ }^{\circ} \mathrm{C}\right)$ was measured with a rectal probe on 3 consecutive days from $3-4$ animals per genotype. Data represent means $\pm S D$.

Core body temperature (Table 1) was measured using a rectal probe (Fine Science Tools) on 3 separate days.

\section{Behavioral assays}

Chemical sensitivity. Eye wipe assays were performed to investigate the afferent functions of the ophthalmic branch of the trigeminal nerve. Capsaicin-induced eye wipes were counted for $1 \mathrm{~min}$ after delivery of 50 $\mu \mathrm{l}$ of solution (50 $\mu \mathrm{M}$ capsaicin). PBS-elicited eye wipes were subtracted from those measured for capsaicin. "Wet dog " shakes were induced by intraperitoneal injection of $50 \mathrm{mg} / \mathrm{kg}$ icilin (Sigma) and whole-body shakes were counted over $30 \mathrm{~min}$, as described previously (Dhaka et al., 2007).

Thermal preference. A two-choice temperature assay was used to determine thermal preference. Mice were placed in an apparatus that had a fixed reference plate set at 25,30 , or $45^{\circ} \mathrm{C}$ and a test plate with the temperature adjusted to between 0 and $50^{\circ} \mathrm{C}$ (T2CT; Bioseb). Each animal was tested twice for each set of parameters. The first assay was initiated by placement of the mouse on the plate set at the test temperature; in the second assay, the initial placement was reversed so that the mouse was placed on the fixed plate. Mouse position was tracked over 5 min using an 
automated tracking system (Bioseb). Only those assays in which mice sampled both plates within the first minute were scored.

Thermal reflex response assays were used to assess acute temperature sensitivity. For hot responses, mice were placed on a plate at $55^{\circ} \mathrm{C}$ and latency to display withdrawal of hind limbs was measured; cutoff to prevent injury was set at $30 \mathrm{~s}$. A cold plantar assay (Brenner et al., 2012) was used to assess sensitivity to low temperatures. For this assay, animals were habituated $(>15 \mathrm{~min})$ in individual chambers with a $1 / 16$ inch glass plate floor, a dry ice pellet was applied below the hindpaw, and the time for paw withdrawal was measured. For each reflex response assay, animals were tested $>3$ times.

\section{In situ hybridization and immunohistochemistry}

In situ hybridization was performed at high stringency (washed $30 \mathrm{~min}$, $0.2 \times \mathrm{SSC}, 70^{\circ} \mathrm{C}$ ) as described previously (Hoon et al., 1999). In situ hybridization of molecular markers was performed on tissue from $>5$ transgenic and control mice. Serial sections from $>10$ sections per mouse were hybridized and the cells counted to quantize numbers of neurons. Immunohistochemistry was performed with chicken anti-GFP (1:1000; Abcam) and rabbit anti-NeuN (1:800; Abcam) and developed with donkey anti-chicken Alexa Fluor 488 or donkey anti-rabbit Alexa Fluor 488 (Jackson ImmunoResearch), respectively. Images were collected using a Microphot FX microscope (Nikon) and images were processed with Adobe Photoshop.

\section{Results}

\section{Selective ablation of TRPV1 and TRPM8 neurons}

Previously, our attempt to ablate the thermoreceptor neurons expressing TRPV1 with constitutively expressed DTA was frustrated because TRPV1 is expressed in the precursors of several functionally distinct classes of nociceptor (Mishra et al., 2011). In the present study, we adopted a different strategy that combined molecular genetic targeting and toxin injection to selectively kill defined classes of these somatosensory neurons in adult mice. This approach makes use of the fact that mice are normally insensitive to DT because they do not express a receptor that mediates cellular uptake of the active toxin. This means that cellspecific DT sensitivity can be achieved by directed expression of the human diphtheria toxin receptor (DTR; Saito et al., 2001). Therefore, to target putative thermoreceptive neurons, we engineered BAC-transgenic mice that express DTR the under the control of TRPV1 and TRPM8 regulatory sequences (Fig. 1a) and used DT injection in adult mice to selective ablate these classes of somatosensory neurons. In situ hybridization studies (Fig. 1b, Fig. $2 a$ ) indicated that TRPV1 neurons are effectively and selectively killed by DT injection in mice expressing the TRPV1-DTR transgene and that TRPM8 neurons (but not other classes of nociceptor) are eliminated in TRPM8-DTR mice. For simplicity, we refer to the toxin-treated animals as TRPV1-DTR and TRPM8-DTR mice, respectively.

Given that approximately one-third of somatosensory neurons express TRPV1, we expected that ablation of this class of somatosensory neuron should result in a dramatic reduction in the total neural count. Indeed, we found that toxin treatment reduced the number of NeuN-positive neurons by $\sim 30 \%$ in the DRG of TRPV1-DTR mice (see Materials and Methods for details). Analysis of interneurons in the spinal cord (Fig. 3) revealed no noticeable differences between mutant and control animals, indicating that TRPV1 cell ablation destroys peripheral input without grossly affecting the somatosensory circuitry. We also noted that the core body temperature of TRPV1-DTR mice remained indistinguishable from that of controls (Table 1). Finally, we assayed capsaicin-induced eye wipes as a high-sensitivity behavioral assay for TRPV1 function and observed no response in TRPV1-DTR animals (Fig. 2b), whereas responses to the TRPM8 a

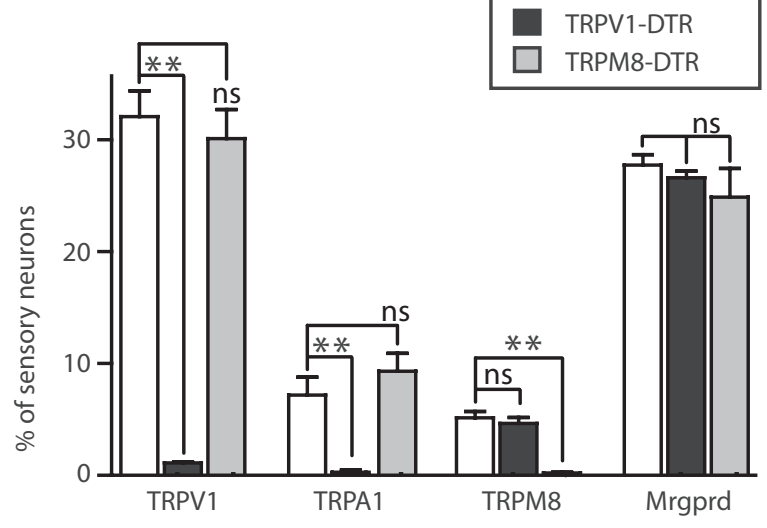

b Capsaicin eye wipes

C

Icilin wet dog shakes
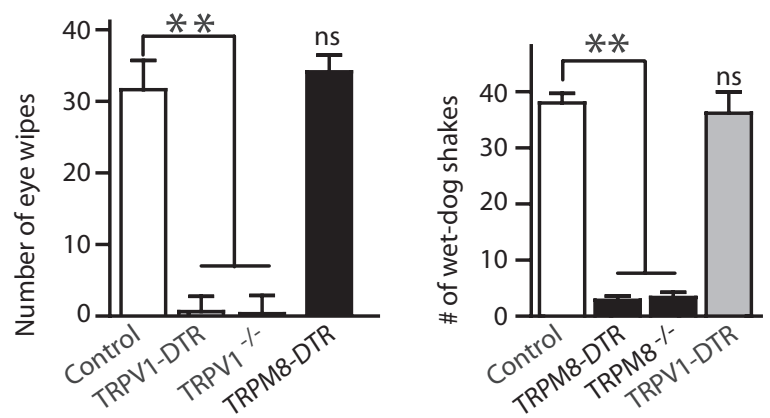

Figure 2. Specific ablation of sensory neurons is achieved by DT treatment of DTR-transgenic mice. $\boldsymbol{a}$, DT treatment of TRPV1-DTR and TPRM8-DTR mice generates animals with specific loss of TRPV1- and TRPM8-expressing neurons. In situ hybridization (ISH) of sections through DRG were probed with molecular markers as indicated. Lumbar DRG from several different mutant mice were analyzed by ISH for expression of TRPV1, TRPA1, TRPM8, and Mrgprd. Serial sections were stained for NeuN-positive neurons to provide a total neuron count. Data represent the percentage of total neurons that were positive by ISH and are shown as means $\pm \operatorname{SEM}(n=3)$; significance was assessed using Student's $t$ test. ${ }^{* *} p<0.01 . \boldsymbol{b}, \boldsymbol{c}$, Capsaicin-elicited eye wipes (b) and icilin-induced wet dog shakes (c) were used to assess loss of TRPV1 and TRPM8 function, respectively. $\boldsymbol{b}$, TRPV1-DTR and TRPV1 ${ }^{-1-}$, but not TRPM8-DTR mice, lose eye-wipe responses. ${ }^{* *} p<0.01$, Student's $t$ test. $c$, In contrast, responses to icilin are lost in TRPM8-DTR and TRPM8 ${ }^{-1-}$ mice, but not TRPV1 mice. ${ }^{* *} p<0.01$, Student's $t$ test. Data represent means \pm SEM ( $n \geq 6$ animals).

agonist icilin remained indistinguishable from those of toxintreated wild-type controls (Fig. 2c). Therefore, TRPV1-DTR animals have a highly selective and essentially complete loss of TRPV1-expressing neurons.

TRPM8 is expressed in a much smaller subset of neurons than TRPV1 (Fig. 1b). Therefore, no significant differences in the number of DRG neurons were detected in TRPM8-DTR mice. However, as expected, behavioral assays showed that these animals were completely unresponsive to the potent TRPM8 agonist icilin (Fig. 2c) whereas they retained responses to capsaicin that were indistinguishable from controls (Fig. 2b). Like the TRPV1DTR mice, TRPM8-DTR mice exhibited completely normal expression of markers of spinal cord interneurons (Fig. 3) and core body temperature (Table 1 ).

We next used a two-plate choice assay to assess temperature preference in TRPV1-DTR and TRPM8-DTR animals. Controls included toxin-treated littermates not carrying the transgenes and TRPV $1^{-1-}$ and TRPM $8^{-1-}$ mice. In essence, the assay allowed us to set the temperature of one plate at a permissive temperature (fixed plate) and to study the response of individual 


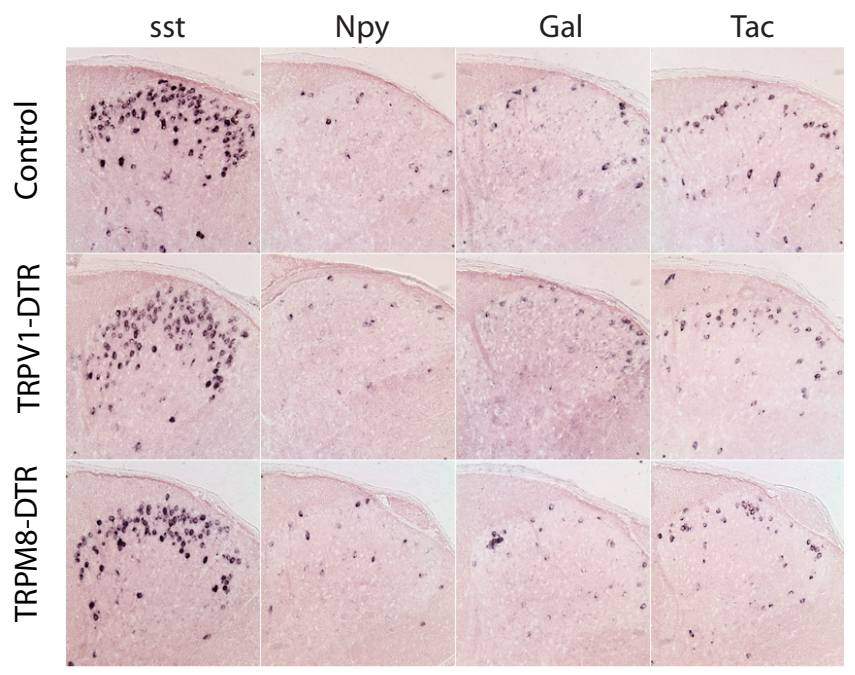

Figure 3. Ablation of TRPV1- and TRPM8-expressing sensory neurons does not alter the numbers of spinal cord interneurons. In situ hybridization was performed with probes to different neuropeptides on sections through the dorsal horn of the spinal cord of control and mutant animals as indicated. No significant differences between genotypes were observed for numbers of positive neurons.

mice to changes in temperature of the other plate (test plate) over a wide and physiologically relevant range of temperatures (from $0-50^{\circ} \mathrm{C}$ ). When the fixed plate was set at $30^{\circ} \mathrm{C}$, control mice showed a clear preference for the test plate at $35^{\circ} \mathrm{C}$ but exhibited increasingly strong avoidance of the plate when the temperature was raised or lowered outside the $25-40^{\circ} \mathrm{C}$ range (Fig. 4 , open circles). TRPV $1^{-1-}$ mice behaved exactly like control animals in this assay (Fig. $4 a$, pink circles). In contrast, DT-mediated ablation of TRPV1 neurons completely eliminated aversion to elevated temperatures $\left(40-50^{\circ} \mathrm{C}\right)$, but did not affect avoidance of cold (Fig. $4 a$, red squares), highlighting the role of TRPV1 cells (but not TRPV1itself) as selectively tuned hot sensors. The opposite phenotype was observed with TRPM8-DTR animals, which exhibited normal aversion to hot temperatures but a striking loss of response to cool and cold (Fig. $4 b$, blue squares). Our data and previous studies (Bautista et al., 2007, Colburn et al., 2007, Dhaka et al., 2007) showed a qualitatively similar phenotype for TRPM $8^{-/-}$mice, with less aversion to $\mathrm{cool}\left(15-25^{\circ} \mathrm{C}\right)$ temperatures than control mice (Fig. $4 b$, pale blue circles; $p<0.05$, Student's $t$ test). However, ablation of TRPM8 cells resulted in a significantly stronger cold $\left(0-15^{\circ} \mathrm{C}\right)$ deficit than knockout of the TRPM8 gene (Fig. 4b). These results confirm the hypothesis that TRPV1 and TRPM8 neurons provide selective, aversive input in response to heat and cold, respectively, and demonstrate that each of these classes of neurons uses unknown thermosensors in addition to either TRPV1 or TRPM8.

\section{A role for TRPA1 in cold detection?}

One prominent, but controversial, candidate cold sensor is the TRP channel TRPA1 (Story et al., 2003, Jordt et al., 2004, Bautista et al., 2006, Kwan et al., 2006, Caspani and Heppenstall, 2009, Karashima et al., 2009, Knowlton et al., 2010). In the present study, we have demonstrated that TRPA1 is not expressed in the cold-sensing TRPM8 cells, but rather is found exclusively in TRPV1-expressing cells (Fig. 2), confirming previous reports (Story et al., 2003, Mishra and Hoon, 2010). Interestingly, TRPM8-DTR mice exhibited modest but appreciable aversion to $0^{\circ} \mathrm{C}$, the lowest temperature tested in the two-plate assay (Fig. $4 b$ ). Therefore, we hypothesized that TRPA1 input (and TRPV1
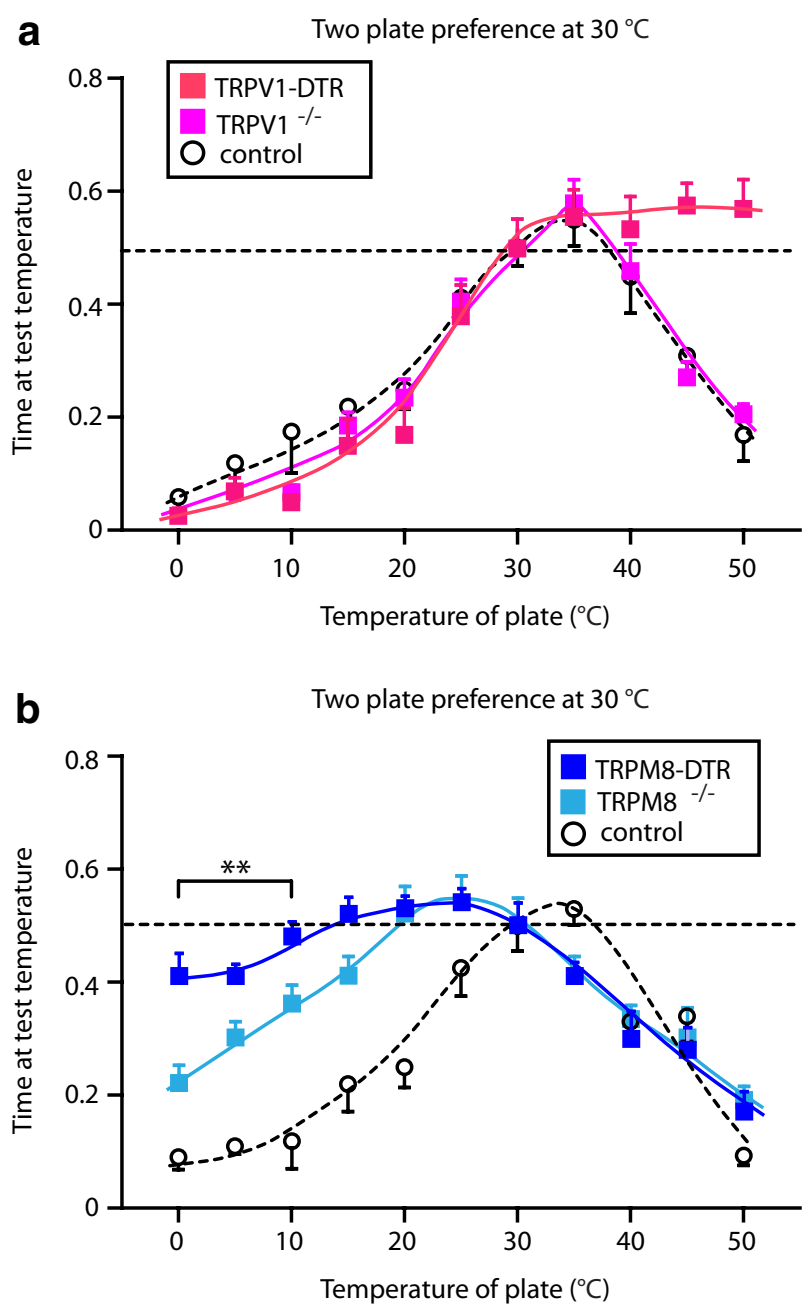

Figure 4. Elimination of TRPV1- and TRPM8-expressing neurons impair avoidance to heat and cold temperatures, respectively. Two-plate preference tests were used to assess thermal responses of TRPV1-DTR and TRPM8-DTR mice. In these experiments, the fixed plate was set at $30^{\circ} \mathrm{C}$. $\boldsymbol{a}$, TRPV1-DTR mice (red squares) show no behavioral responses to hot temperatures $\left(45-50^{\circ} \mathrm{C} ; p<0.01\right.$, Student's $t$ test) that are strongly aversive to control mice (TRPV1-DTR nontransgenic DT-treated littermates; open circles). In contrast, TRPV1 ${ }^{-1-}$ animals (pink squares) exhibit responses that are indistinguishable from controls. $\boldsymbol{b}$, TRPM8-DTR mice (dark blue squares) have greatly attenuated responses to cold compared with controls (TRPM8-DTR nontransgenic DT-treated littermates; open circles), but retain strong aversion to heat. Significant differences between genotypes were observed from $0-25^{\circ} \mathrm{C}$ and at $35^{\circ} \mathrm{C}(p<0.01$, Student's $t$ test). TRPM8 ${ }^{-1-}$ mutants (pale blue squares) are also less sensitive to cool temperatures $\left(5-20^{\circ} \mathrm{C}\right)$ than controls, but are significantly more responsive to cold $\left(0-10^{\circ} \mathrm{C}\right)$ than TRPM8-DTR mice ( ${ }^{\#} p<0.05$, Student's $t$ test). Time at test temperature represents the fraction of time mice spent on the test plate versus the fixed plate; data are means \pm SEM ( $n \geq 6$ animals).

cells) might be involved in triggering aversion to painful cold in TRPM8-DTR mice.

To test this hypothesis, we first confirmed that TRPA1 expression is eliminated in TRPV1-DTR mice (Fig. $5 a$, Fig $2 a$ ). Next, we used a cold plantar assay (Brenner et al., 2012) to investigate whether TRPV1 cell input affected an animal's tolerance of noxious cold. In this assay, paw withdrawal latency was measured after application of a piece of dry ice to the glass plate directly under the mouse's hindpaw (rapid cooling of the plantar surface). As expected, knockout of TRPM8 or ablation of TRPM8 cells significantly increased the time it took for mice to respond (Fig. $5 b$ ) and, in agreement with the two-plate preference assay, ablation of the TRPM8 cells resulted in a more profound deficit 

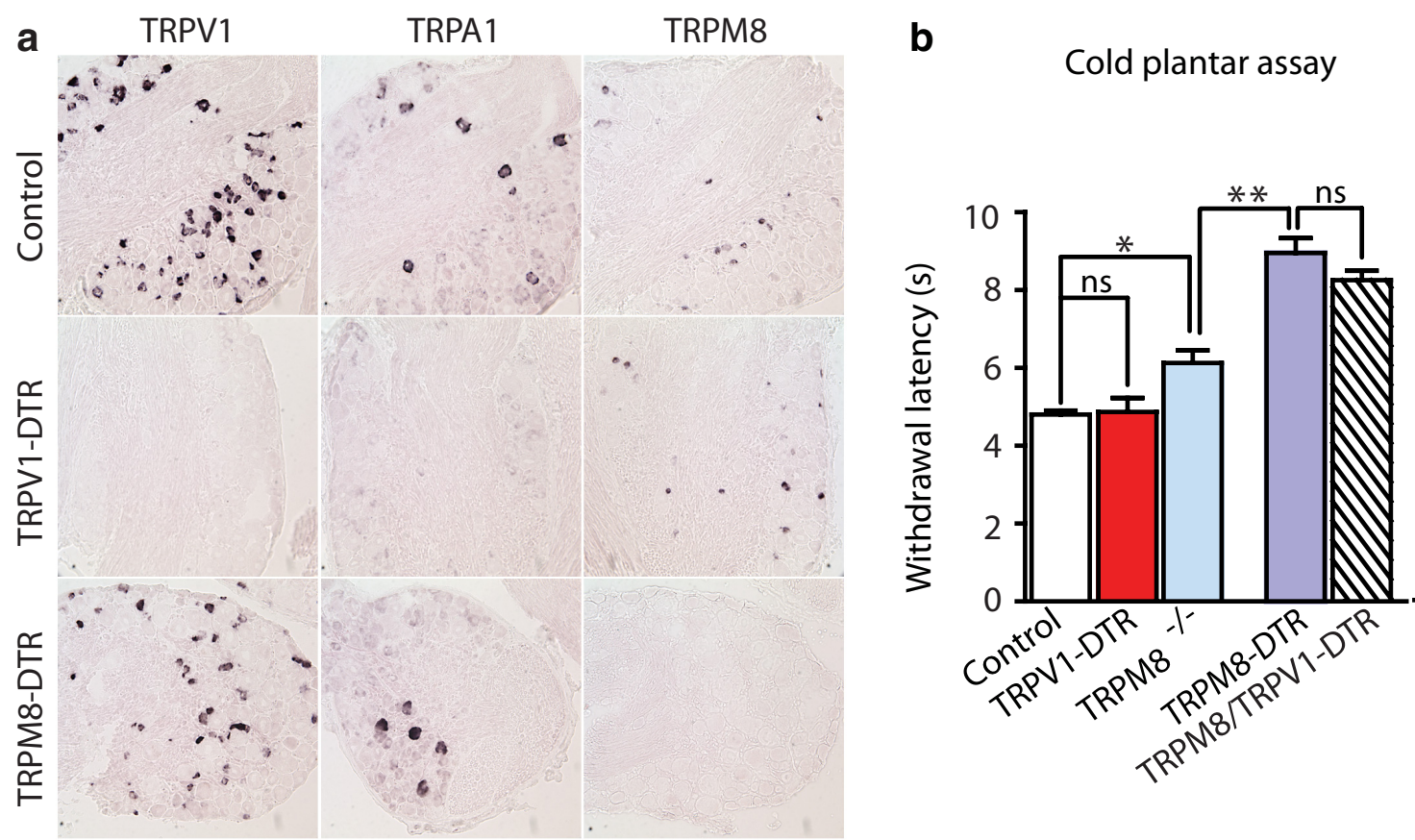

Figure 5. TRPA1-expressing neurons do not play a detectable role in cold reflex behavioral responses. $\boldsymbol{a}$, In situ hybridization of sections through DRG was used to examine TRPA1 expression. After ablation of TRPV1 neurons, all TRPA1 expression was lost. $\boldsymbol{b}$, A cold plantar assay was used to assess responses of various mutant mice to rapid cooling. In this assay, TRPM 8 - I- mutants (pale blue bar) are less sensitive than controls $\left({ }^{*} p<0.05\right.$, Student's $t$ test), but are significantly more responsive than TRPM8-DTR mice ( ${ }^{* *} p<0.01$, Student's $t$ test). In contrast, loss of TRPA1 input (elimination of TRPV1 cells) had no effect on paw withdrawal (TRPV1-DTR; red bar) even in mice in which TRPM8 cold-responsive cells were also killed (TRPV1-DTR/TRPM8-DTR; hashed bar). Data represent means \pm SEM ( $n \geq 6$ animals).

in cold sensing than was observed in TRPM8 ${ }^{-1-}$ mice. In contrast, TRPV1-DTR mice displayed reaction times that were no different from control animals and, more importantly, the responses of TRPV1-DTR/TRPM8-DTR animals were indistinguishable from those of TRPM8-DTR animals (Fig. 5b). Therefore, TRPA1 has no major role in this type of cold reflex responses.

\section{Painful temperatures activate Mrgprd-expressing neurons}

Which cells mediate the residual responses to cold in TRPM8DTR animals? We showed previously that TRPV1-DTA mice, which lack several classes of sensory neuron because the TRPV1 lineage is ablated during development, were completely insensitive to cold in the two-plate assay (Mishra et al., 2011). Therefore, we suspected that other nociceptors that are lost in TRPV1-DTA mice might be involved and set out to investigate whether Mrgprd-expressing neurons augment cold sensation through TRPM8 neurons at very low temperatures. We obtained the previously reported Mrgprd-DTR knock-in line (Cavanaugh et al., 2009; a generous gift from David Anderson) and confirmed that these mice had no significant cold-sensing phenotype (Fig. $6 b$, light gray bar). Next, we crossed the Mrgprd-DTR allele into a TRPM8-DTR background to ablate both sets of neurons (Fig. 6a) and found that these mice exhibited significantly less cold sensitivity than TRPM8-DTR mice in the cold plantar assay of noxious cold (Fig. 6b, dark gray bar). Therefore, Mrgprd cells not only detect mechanical pain (Cavanaugh et al., 2009), but also respond to extreme cold. Nonetheless, the TRPV1-DTA mice that we described previously (Mishra et al., 2011) have an even greater deficit in cold sensation than the Mrgprd-DTR/TRPM8-DTR double mutants, implying that additional TRPV1 lineage cells may also respond to painfully cold temperatures. Could the functional responses of TRPV1 cells to cold, which was unmasked by ablating both TRPM8 and Mrgprd neurons, account for this difference? To answer this question, we generated and tested triple mutants lacking TRPV1, TRPM8, and Mrgprd neurons. These mice (Fig. 6b, hatched bar) were indistinguishable in their response to cold from the double mutants that still had normal TRPV1 input (Fig. 6b, dark gray bar). Therefore, our data demonstrate that TRPV1 cells play a very minor role (if any) in cold detection and, because TRPA1 is expressed exclusively in TRPV1 cells, further limit the role that this protein can have as a cold detector.

We also examined responses of mutant animals to painful heat. Because exposure to temperatures $>50^{\circ} \mathrm{C}$ needs to be strictly limited to prevent injury, we could not use the two-plate preference test and instead used paw withdrawal from a $55^{\circ} \mathrm{C}$ heated block with a $30 \mathrm{~s}$ exposure maximum to assay noxious heat. As shown previously (Mishra et al., 2011), TRPV1-DTA mice exhibited no escape reaction within the cutoff (Fig. $7 b$, black bar). However, although the TRPV1-DTR mice were far less sensitive to heat than controls, they still exhibited paw withdrawal within the 30 s cutoff (Fig. $7 b$, red bar). Do Mrgprd cells contribute to responses to painful heat as well as noxious cold? Again, we generated double mutant animals, this time TRPV1-DTR/ Mrgprd-DTR, demonstrated efficient ablation of both populations of sensory neurons (Fig. 7a), and tested behavioral responses. Just as we observed for cold sensation, ablation of Mrgprd cells alone had no effect on paw withdrawal latency, but when combined with ablation of TRPV1 cells, it significantly increased reaction times to high temperature (Fig. $7 b$ ). Indeed, just like the TRPV1-DTA animals, TRPV1-DTR/Mrgprd-DTR mice were almost completely insensitive to $55^{\circ} \mathrm{C}$ exposure. These results show that Mrgprd neurons respond to extremes of heat and cold and may enhance escape reactions (as well as modify the sensory experience) to these noxious and painful stimuli. 


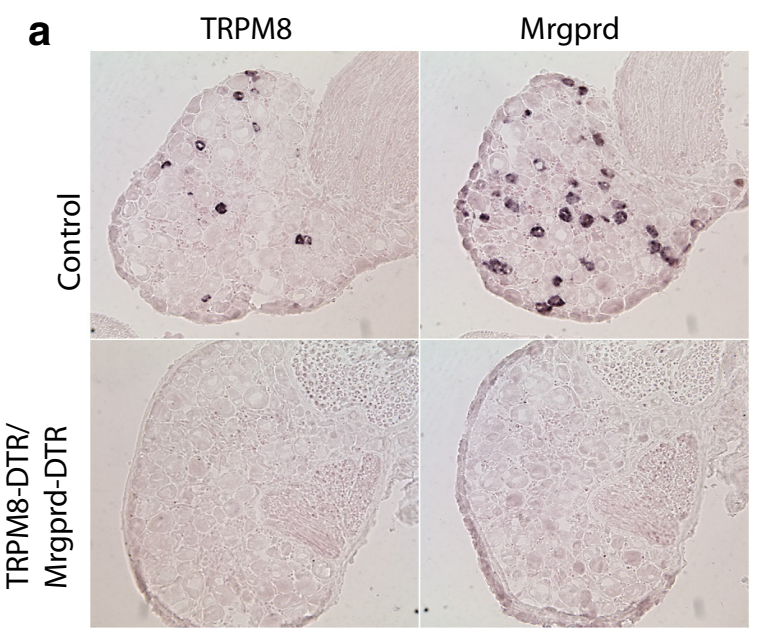

b

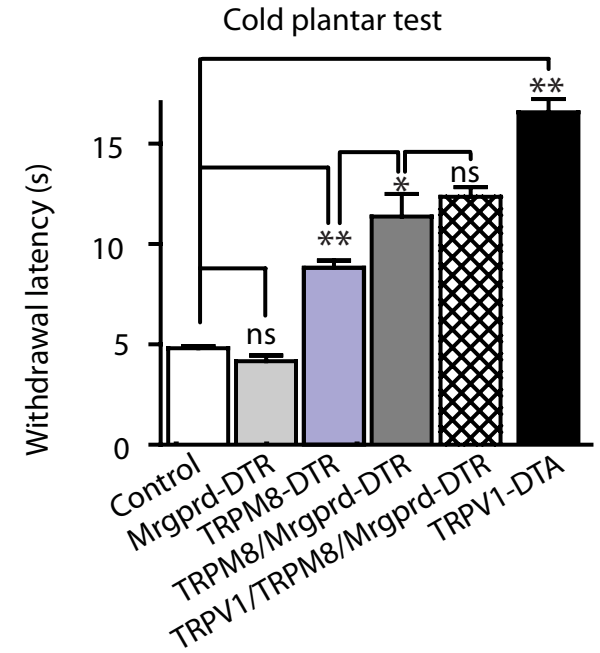

Figure 6. Mrgprd neurons contribute to the detection of noxious cold. $\boldsymbol{a}$, Representative in situ hybridization of sections through DRG from TRPM8-DTR/Mrgprd-DTR mice illustrates selective loss of TRPM8- and Mrgprd-expressing cells. $\boldsymbol{b}$, In cold plantar tests, TRPM8-DTR mice (blue bars) have significantly longer withdrawal latencies than controls ( ${ }^{* *} p<0.01$, Student's $t$ test). In contrast, behavioral responses of Mrgprd-DTR mice (gray bars) were indistinguishable from controls (n.S., Student's $t$ test). Combined loss of TRPM8 and Mrgprd neurons (dark gray bars) causes a significantly greater cold deficit than ablation of TRPM8 cells alone ( ${ }^{*} p<0.05$, Student's $t$ test). Elimination of TRPV1 cells in addition to the TRPM 8 and Mrgprd cells (crosshatched bar) had no additional effect on paw withdrawal latency. As expected, TRPV1-DTA mutants (mice with an extensive loss of TRPV1-lineage neurons, black bar) exhibit significantly reduced withdrawal latency compared with controls and other genotypes $\left({ }^{* *} p<0.01\right.$, Student's $t$ test). Data represent means \pm SEM ( $n \geq 6$ animals).

Attraction to warmth is mediated by TRPV1 and TRPM8 cells Interestingly, TRPM8-DTR mice not only showed reduced responses to cold temperatures in the two-plate preference assay, but also a marked shift in their preferred temperature: from $35^{\circ} \mathrm{C}$ in control animals to $25^{\circ} \mathrm{C}$ in the mutants (Fig. 4). Therefore, we set out to investigate how TRPV1 and TRPM8 neurons affect the perception of warmth (i.e., the temperature range that a normal mouse actively seeks out). To do this, we again used the two-plate assay, but initially decreased the temperature of the fixed plate to $25^{\circ} \mathrm{C}$, the preference maximum for TRPM8-DTR mice (Fig. 4). Under these conditions, control mice preferred to remain on the warmer block at temperatures up to and including $40^{\circ} \mathrm{C}$, but still strongly disliked higher temperatures (Fig. 8a). TRPV1-DTR animals behaved indistinguishably from controls in the warm (30$40^{\circ} \mathrm{C}$ ) regime, but, unlike controls, continued to show increased

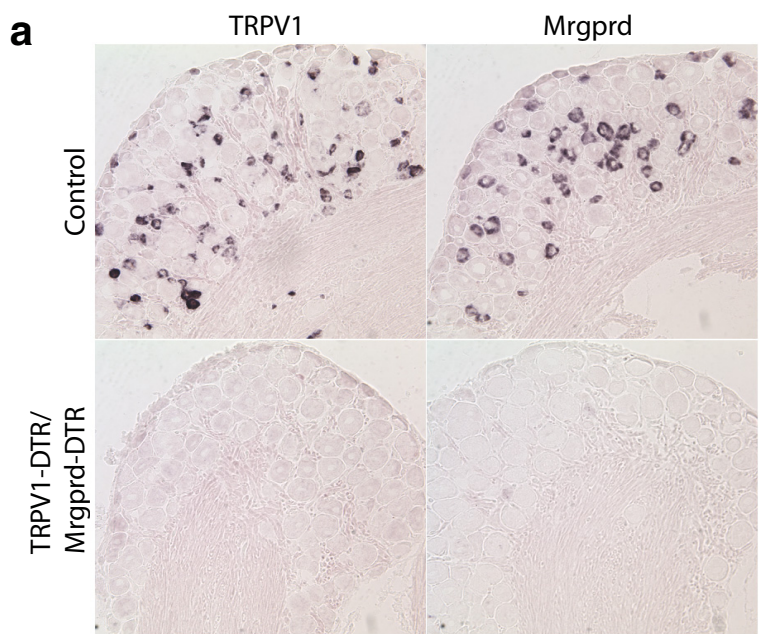

b Hot plate assay $55^{\circ} \mathrm{C}$

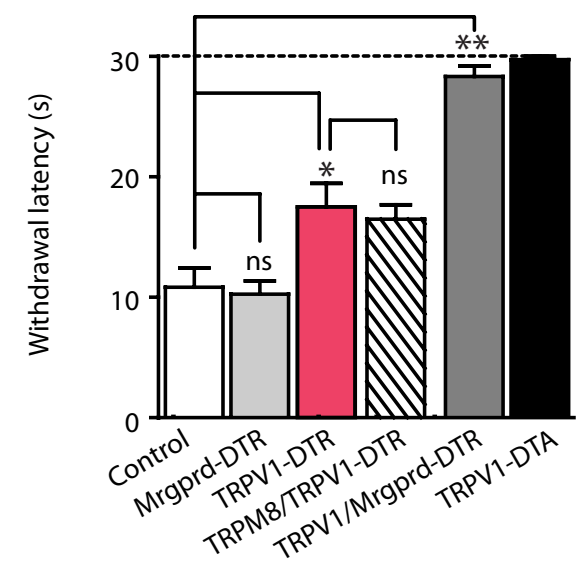

Figure 7. Mrgprd neurons contribute to the detection of painful heat. $\boldsymbol{a}$, Representative in situ hybridization of sections through DRG from TRPV1-DTR/Mrgprd-DTR mice illustrates selective loss of TRPV1- and Mrgprd-expressing cells. $\boldsymbol{b}, \mathrm{A}$ standard hot plate test that measures latency to show escape reactions to $55^{\circ} \mathrm{C}$ was used to examine responses to noxious heat; significant differences between genotypes were assessed using Student's $t$ test. Mrgprd-DTR mice (pale gray bar) display withdrawal responses indistinguishable from controls (open bar), whereas TRPV1-DTR mice (red bars) exhibit reduced response to noxious heat ( ${ }^{*} p<0.05$ ). Additional ablation of TRPM8 cells (hatched bar) had no significant effect on response latency. In contrast, double mutants in which both the TRPV1 and Mrgprd cells were eliminated (dark gray bar) and TRPV1-DTA mice that extensively lack both of these classes of nociceptor (black bar) were essentially unresponsive within the cutoff for this assay. Data represent means \pm SEM ( $n \geq 6$ animals).

preference for the test plate even at temperatures that are normally strongly aversive (up to $50^{\circ} \mathrm{C}$; Fig. $8 a$, red squares). As predicted, TRPM8-DTR mice exhibited a completely different phenotype. These animals were never attracted to the warmer environment and showed progressively increasing aversion at temperatures of $35^{\circ} \mathrm{C}$ and above (Fig. $8 a$ ).

We also subjected animals to the opposite scenario, in which the fixed block was set at a modestly aversive elevated temperature $\left(45^{\circ} \mathrm{C}\right)$. In this assay, normal mice chose to stay at cooler test temperatures far longer than when the fixed block was set at $30^{\circ} \mathrm{C}$ (compare Fig. 8b, Fig. 4). As expected, TRPV1-DTR mice showed strong preference for $45^{\circ} \mathrm{C}$ at all temperatures tested (Fig. $8 b$ ), whereas TRPM8-DTR mice always preferred the colder temperature even when the test block was set at $0^{\circ} \mathrm{C}$ (Fig. $8 b$, blue squares). These data indicate that the threshold for TRPM8mediated aversion is $\sim 35^{\circ} \mathrm{C}$ (body temperature), and suggest 
a

Two plate preference at $25^{\circ} \mathrm{C}$

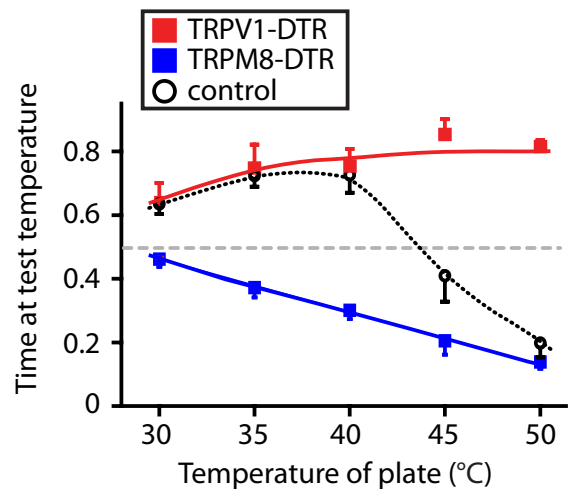

C Two plate preference at $25^{\circ} \mathrm{C}$

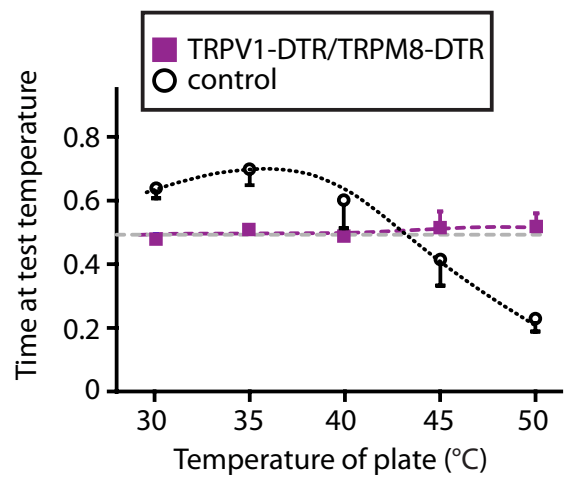

b Two plate preference at $45^{\circ} \mathrm{C}$

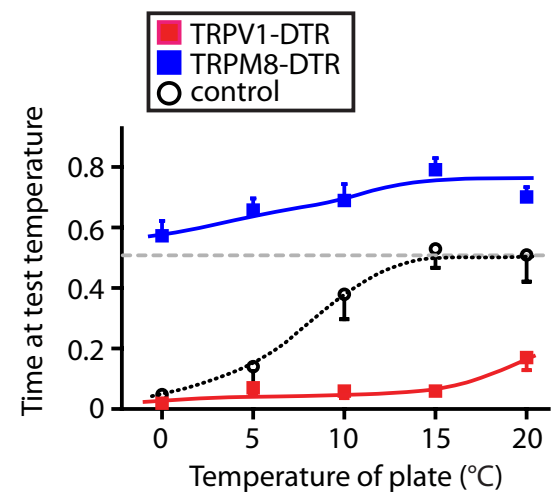

d Two plate preference at $45^{\circ} \mathrm{C}$

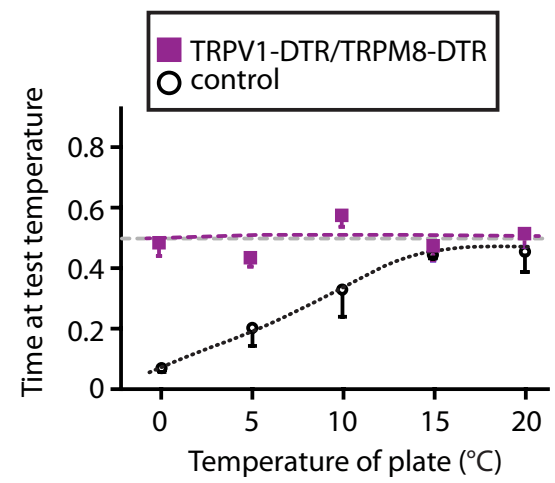

Figure 8. TRPV1 and TRPM8 neurons code for hot, cold, and warm stimuli. $\boldsymbol{a}$, In two-plate choice assays with the fixed plate set at $25^{\circ} \mathrm{C}$, TRPV1-DTR mice (red squares) exhibit marked preference for test temperatures $\geq 40^{\circ} \mathrm{C}$, whereas their control littermates (open circles) display profound avoidance to $45-50^{\circ} \mathrm{C}$. In contrast, TRPM8-DTR animals (blue squares) display no preference for warm and show increasing avoidance as temperature rises $>35^{\circ} \mathrm{C}$. $\boldsymbol{b}$, When the fixed plate was set at $45^{\circ} \mathrm{C}$, TRPM8-DTR mice (blue squares) preferred all colder temperatures, whereas TRPV1-DTR animals (red squares) were significantly more averse to cold than controls (red squares) over the $10-20^{\circ} \mathrm{C}$ temperature range ( $p<0.01$, Student's $t$ test). $\boldsymbol{c}, \boldsymbol{d}$, Mice with combined loss of TRPV1and TRPM8-expressing cells (TRPV1-DTR/TRPM8-DTR, purple squares) were also tested using the two-plate preference assay with the fixed plate set at $25^{\circ} \mathrm{C}(\boldsymbol{c})$ or $45^{\circ} \mathrm{C}(\boldsymbol{d})$. The double mutant animals exhibited no temperature preference across the full range of temperatures. Time at test temperature represents the fraction of time mice spent on the test plate versus the control plate. Data represent means \pm SEM ( $n \geq 6$ animals).

that TRPV1 and TRPM8 neurons provide all thermosensitive input from the periphery. If this is true, then the simplest explanation for the sensation of warmth would be that it reflects the absence of aversive signaling from either cold- or hot-sensing neurons rather than a positive signal from another class of thermoreceptor. This model predicts that ablation of both hot- and cold-sensing neurons should yield mice that cannot detect warmth. Figure 8, $c$ and $d$, demonstrates that TRPV1-DTR/ TRPM8-DTR animals failed to exhibit attraction to temperatures that normal animals actively sought out and were essentially indifferent to temperatures between 0 and $50^{\circ} \mathrm{C}$. Therefore, input through the TRPM8 and TRPV1 cells not only alerts mice to unpleasant or noxious temperatures, but also determines their preferred temperature range and control responses to warmth.

\section{Discussion}

In the present study, we used a selective ablation strategy to explore the contribution of individual, molecularly defined classes of sensory neuron to the mammalian sense of temperature. The DTR transgenes that we developed are very selectively expressed in sensory neurons (see Materials and Methods for details), and ablation of each class of cell was specific and had no detectable effects on other sensory neurons (Fig. 1, Fig. 2) or the wider somatosensory circuitry (Fig. 3). Moreover, DT treatment of the different transgenic mice resulted in reproducible, highly selective, and nonoverlapping effects on animal behavior, thus ruling out nonspecific effects of this experimental technique. Similar approaches have been validated extensively in previous studies of the peripheral nervous system (Gogos et al., 2000, Cavanaugh et al., 2009), CNS (Luquet et al., 2005) and for other sensory systems (Huang et al., 2006). Therefore, our results demonstrate that thermosensation almost exclusively uses two differentially tuned populations of sensory neurons: TRPV1 cells that respond to high temperature and TRPM8 cells that detect cold to encode a full range of sensory percepts (cold, cool, warm, and hot). Interestingly, thermoreception in fruit flies closely parallels its mammalian counterpart and also uses separate populations of hot- and coldresponsive neurons to encode the full temperature range (Gallio et al., 2011), perhaps reflecting a common evolutionary need of animals to avoid temperature extremes.

In our experiments, ablating TRPV1 cells but not knockout of the TRPV1 channel itself, had major effects on an animal's ability to detect elevated temperatures as high as $50^{\circ} \mathrm{C}$, implying that these cells must express novel heat sensors in addition to TRPV1. Similarly, although TRPM8 serves as an important receptor for cooling (Bautista et al., 2007, Colburn et al., 2007, Dhaka et al., 2007), the greater thermal deficit of TRPM8-DTR mice compared with knockouts (Fig. 4, Fig. 5) indicates that additional cold receptors are activated in these neurons when temperatures decrease to $<15^{\circ} \mathrm{C}$. Our data also demonstrate that extremes of heat and cold recruit at least one more class of nociceptors, the cells expressing Mrgprd, which are not normally thought to respond to thermal cues (Cavanaugh et al., 2009). Although it is possible that these neurons in fact are a class of thermosensor that only respond to temperature extremes, we favor a model in which the known sensitivity of Mrgprd nociceptors to inflammatory and algesic compounds (Dussor et al., 2008, Rau et al., 2009) accounts for their recruitment by both noxious heat and noxious cold. In contrast, no role for TRPV1 cells (and, by implication, the TRPA1 channel) was detected in responses to low temperatures (Fig. 4, Fig. 5, Fig. 6).

Are TRPV1 and TRPA1 required for any types of thermal response? Our study was primarily designed to uncover the role of specific cells types in somatosensation rather than the role of specific receptors. Nonetheless, we found little evidence that either channel is directly involved in detecting thermal cues over a wide, physiologically relevant temperature range. Our data are largely consistent with previous reports (Caterina et al., 2000, Bautista et al., 2006) in the temperature range $\left(0-50^{\circ} \mathrm{C}\right)$ that we studied. The biggest effects of TRPV1 on heat detection appear at 
more extreme temperatures and after injury or inflammation (Caterina et al., 2000), conditions not investigated in our study. Similarly, TRPA1 may have a more significant role as a cold transducer after injury (del Camino et al., 2010) and it is possible that cellular coding is also modified in these circumstances. However, in normal mice, TRPA1 neither affects temperature preference nor withdrawal responses from cold, thus challenging the notion (Kwan et al., 2006, Karashima et al., 2009) that TRPA1 is a cold temperature sensor in the absence of injury.

Ablation of TRPM8 neurons caused major temperature detection deficits in the warm temperature range (up to $35^{\circ} \mathrm{C}$; Fig. 4 , Fig. 8), which is consistent with previous in vivo studies (de la Peña et al., 2005, Madrid et al., 2009, Sarria et al., 2012) finding similar tuning using functional modulation of these cells. Together with the flat temperature response profile of TRPV1-DTR/ TRPM8-DTR double mutant animals, the most parsimonious explanation for the feeling of warmth is that this percept actually reflects minimal signaling through the TRPM8 cells (and little or no input from TRPV1 cells). However, because TRPV1-expressing neurons (and their TRPM8 counterparts) may not be homogeneous populations of thermosensors, we cannot completely exclude more complex scenarios, for example, that a subset of TRPV1 neurons is tuned to respond to warm temperatures and provides attractive rather than aversive input.

How would the simple model (lack of aversive input through TRPM8 and TRPV1 neurons) fit with our own experience? Although it is practically impossible to extrapolate human perception to behavioral studies of mice, it remains likely that a very similar peripheral mechanism accounts for temperature detection in both species. The separate inputs of cooling and heating nicely explain our ability to distinguish cold from hot and why inflammation and injury, which increase responses through TRPV1 cells (Caterina and Julius, 2001), make normally pleasant heat unbearable. Other familiar experiences, such as the soothing effects of a cool breeze or menthol, the thermal grill illusion (Craig, 2002), or the painful effects of going from a freezing environment to a warm one, suggest significant and complex interactions between these two distinct sensory lines. Finally, our evaluation of temperature (and the valence assigned to stimuli) can vary greatly according to our core temperature. Therefore, we anticipate that future studies mapping the connections and circuitry of the afferent TRPM8 and TRPV1 sensory lines will be useful in explaining how sensation drives temperature perception and how this information interacts with internal and emotional states to control behavior.

\section{References}

Bautista DM, Jordt SE, Nikai T, Tsuruda PR, Read AJ, Poblete J, Yamoah EN, Basbaum AI, Julius D (2006) TRPA1 mediates the inflammatory actions of environmental irritants and proalgesic agents. Cell 124:1269-1282. CrossRef Medline

Bautista DM, Siemens J, Glazer JM, Tsuruda PR, Basbaum AI, Stucky CL, Jordt SE, Julius D (2007) The menthol receptor TRPM8 is the principal detector of environmental cold. Nature 448:204-208. CrossRef Medline

Brenner DS, Golden JP, Gereau RW 4th (2012) A novel behavioral assay for measuring cold sensation in mice. PLoS One 7:e39765. CrossRef Medline

Caspani O, Heppenstall PA (2009) TRPA1 and cold transduction: an unresolved issue? J Gen Physiol 133:245-249. CrossRef Medline

Caterina MJ, Julius D (2001) The vanilloid receptor: a molecular gateway to the pain pathway. Annu Rev Neurosci 24:487-517. CrossRef Medline

Caterina MJ, Schumacher MA, Tominaga M, Rosen TA, Levine JD, Julius D (1997) The capsaicin receptor: a heat-activated ion channel in the pain pathway. Nature 389:816-824. CrossRef Medline

Caterina MJ, Leffler A, Malmberg AB, Martin WJ, Trafton J, Petersen-Zeitz KR, Koltzenburg M, Basbaum AI, Julius D (2000) Impaired nociception and pain sensation in mice lacking the capsaicin receptor. Science 288: 306-313. CrossRef Medline

Cavanaugh DJ, Lee H, Lo L, Shields SD, Zylka MJ, Basbaum AI, Anderson DJ (2009) Distinct subsets of unmyelinated primary sensory fibers mediate behavioral responses to noxious thermal and mechanical stimuli. Proc Natl Acad Sci U S A 106:9075-9080. CrossRef Medline

Cavanaugh DJ, Chesler AT, Jackson AC, Sigal YM, Yamanaka H, Grant R, O'Donnell D, Nicoll RA, Shah NM, Julius D, Basbaum AI (2011) Trpv1 reporter mice reveal highly restricted brain distribution and functional expression in arteriolar smooth muscle cells. J Neurosci 31:5067-5077. CrossRef Medline

Colburn RW, Lubin ML, Stone DJ Jr, Wang Y, Lawrence D, D’Andrea MR, Brandt MR, Liu Y, Flores CM, Qin N (2007) Attenuated cold sensitivity in TRPM8 null mice. Neuron 54:379-386. CrossRef Medline

Craig AD (2002) How do you feel? Interoception: the sense of the physiological condition of the body. Nat Rev Neurosci 3:655-666. CrossRef Medline

de la Peña E, Mälkiä A, Cabedo H, Belmonte C, Viana F (2005) The contribution of TRPM8 channels to cold sensing in mammalian neurones. J Physiol 567:415-426. CrossRef Medline

del Camino D, Murphy S, Heiry M, Barrett LB, Earley TJ, Cook CA, Petrus MJ, Zhao M, D'Amours M, Deering N, Brenner GJ, Costigan M, Hayward NJ, Chong JA, Fanger CM, Woolf CJ, Patapoutian A, Moran MM (2010) TRPA1 contributes to cold hypersensitivity. J Neurosci 30:15165-15174. CrossRef Medline

Dhaka A, Murray AN, Mathur J, Earley TJ, Petrus MJ, Patapoutian A (2007) TRPM8 is required for cold sensation in mice. Neuron 54:371-378. CrossRef Medline

Dussor G, Zylka MJ, Anderson DJ, McCleskey EW (2008) Cutaneous sensory neurons expressing the Mrgprd receptor sense extracellular ATP and are putative nociceptors. J Neurophysiol 99:1581-1589. CrossRef Medline

Gallio M, Ofstad TA, Macpherson LJ, Wang JW, Zuker CS (2011) The coding of temperature in the Drosophila brain. Cell 144:614-624. CrossRef Medline

Gogos JA, Osborne J, Nemes A, Mendelsohn M, Axel R (2000) Genetic ablation and restoration of the olfactory topographic map. Cell 103:609620. CrossRef Medline

Hoon MA, Adler E, Lindemeier J, Battey JF, Ryba NJ, Zuker CS (1999) Putative mammalian taste receptors: a class of taste-specific GPCRs with distinct topographic selectivity. Cell 96:541-551. CrossRef Medline

Huang AL, Chen X, Hoon MA, Chandrashekar J, Guo W, Tränkner D, Ryba NJ, Zuker CS (2006) The cells and logic for mammalian sour taste detection. Nature 442:934-938. CrossRef Medline

Jordt SE, McKemy DD, Julius D (2003) Lessons from peppers and peppermint: the molecular logic of thermosensation. Curr Opin Neurobiol 13: 487-492. CrossRef Medline

Jordt SE, Bautista DM, Chuang HH, McKemy DD, Zygmunt PM, Högestätt ED, Meng ID, Julius D (2004) Mustard oils and cannabinoids excite sensory nerve fibres through the TRP channel ANKTM1. Nature 427: 260-265. CrossRef Medline

Karai L, Brown DC, Mannes AJ, Connelly ST, Brown J, Gandal M, Wellisch OM, Neubert JK, Olah Z, Iadarola MJ (2004) Deletion of vanilloid receptor 1-expressing primary afferent neurons for pain control. J Clin Invest 113:1344-1352. CrossRef Medline

Karashima Y, Talavera K, Everaerts W, Janssens A, Kwan KY, Vennekens R, Nilius B, Voets T (2009) TRPA1 acts as a cold sensor in vitro and in vivo. Proc Natl Acad Sci U S A 106:1273-1278. CrossRef Medline

Knowlton WM, Bifolck-Fisher A, Bautista DM, McKemy DD (2010) TRPM8, but not TRPA1, is required for neural and behavioral responses to acute noxious cold temperatures and cold-mimetics in vivo. Pain 150: 340-350. CrossRef Medline

Kwan KY, Allchorne AJ, Vollrath MA, Christensen AP, Zhang DS, Woolf CJ, Corey DP (2006) TRPA1 contributes to cold, mechanical, and chemical nociception but is not essential for hair-cell transduction. Neuron 50: 277-289. CrossRef Medline

Lee EC, Yu D, Martinez de Velasco J, Tessarollo L, Swing DA, Court DL, Jenkins NA, Copeland NG (2001) A highly efficient Escherichia colibased chromosome engineering system adapted for recombinogenic targeting and subcloning of BAC DNA. Genomics 73:56-65. CrossRef Medline

Luquet S, Perez FA, Hnasko TS, Palmiter RD (2005) NPY/AgRP neurons 
are essential for feeding in adult mice but can be ablated in neonates. Science 310:683-685. CrossRef Medline

Madrid R, de la Peña E, Donovan-Rodriguez T, Belmonte C, Viana F (2009) Variable threshold of trigeminal cold-thermosensitive neurons is determined by a balance between TRPM8 and Kv1 potassium channels. J Neurosci 29:3120-3131. CrossRef Medline

McKemy DD, Neuhausser WM, Julius D (2002) Identification of a cold receptor reveals a general role for TRP channels in thermosensation. Nature 416:52-58. CrossRef Medline

Mishra SK, Hoon MA (2010) Ablation of TrpV1 neurons reveals their selective role in thermal pain sensation. Mol Cell Neurosci 43:157-163. CrossRef Medline

Mishra SK, Tisel SM, Orestes P, Bhangoo SK, Hoon MA (2011) TRPV1lineage neurons are required for thermal sensation. EMBO J 30:582-593. CrossRef Medline

Park U, Vastani N, Guan Y, Raja SN, Koltzenburg M, Caterina MJ (2011) TRP vanilloid 2 knock-out mice are susceptible to perinatal lethality but display normal thermal and mechanical nociception. J Neurosci 31: 11425-11436. CrossRef Medline

Patapoutian A, Peier AM, Story GM, Viswanath V (2003) ThermoTRP channels and beyond: mechanisms of temperature sensation. Nat Rev Neurosci 4:529-539. CrossRef Medline

Peier AM, Moqrich A, Hergarden AC, Reeve AJ, Andersson DA, Story GM, Earley TJ, Dragoni I, McIntyre P, Bevan S, Patapoutian A (2002) A TRP channel that senses cold stimuli and menthol. Cell 108:705-715. CrossRef Medline
Rau KK, Mcllwrath SL, Wang H, Lawson JJ, Jankowski MP, Zylka MJ, Anderson DJ, Koerber HR (2009) Mrgprd enhances excitability in specific populations of cutaneous murine polymodal nociceptors. J Neurosci 29: 8612-8619. CrossRef Medline

Saito M, Iwawaki T, Taya C, Yonekawa H, Noda M, Inui Y, Mekada E, Kimata Y, Tsuru A, Kohno K (2001) Diphtheria toxin receptor-mediated conditional and targeted cell ablation in transgenic mice. Nat Biotechnol 19:746-750. CrossRef Medline

Sarria I, Ling J, Xu GY, Gu JG (2012) Sensory discrimination between innocuous and noxious cold by TRPM8-expressing DRG neurons of rats. Mol Pain 8:79. CrossRef Medline

Story GM, Peier AM, Reeve AJ, Eid SR, Mosbacher J, Hricik TR, Earley TJ, Hergarden AC, Andersson DA, Hwang SW, McIntyre P, Jegla T, Bevan S, Patapoutian A (2003) ANKTM1, a TRP-like channel expressed in nociceptive neurons, is activated by cold temperatures. Cell 112:819-829. CrossRef Medline

Vriens J, Owsianik G, Hofmann T, Philipp SE, Stab J, Chen X, Benoit M, Xue F, Janssens A, Kerselaers S, Oberwinkler J, Vennekens R, Gudermann T, Nilius B, Voets T (2011) TRPM3 is a nociceptor channel involved in the detection of noxious heat. Neuron 70:482-494. CrossRef Medline

Woodbury CJ, Zwick M, Wang S, Lawson JJ, Caterina MJ, Koltzenburg M, Albers KM, Koerber HR, Davis BM (2004) Nociceptors lacking TRPV1 and TRPV2 have normal heat responses. J Neurosci 24:6410-6415. CrossRef Medline

Woolf CJ, Ma Q (2007) Nociceptors-noxious stimulus detectors. Neuron 55:353-364. CrossRef Medline 